\title{
1 Opposing effects of plant-community assembly maintain constant 2 litter decomposition over grasslands aged from 1 to 25 years
}

3 L. Barbe ${ }^{1}$, A. Prinzing ${ }^{1}$, C. Mony ${ }^{1}$, B. W. Abbott ${ }^{1,2}$, M. Santonja ${ }^{1}$, K. Hoeffner ${ }^{1}$, S. 4 Guillocheau $^{1}$, D. Cluzeau ${ }^{1}$, A.-J. Francez ${ }^{1}$, N. Le Bris ${ }^{1}$ and V. Jung ${ }^{1}$

$6 \quad{ }^{1}$ ECOBIO, OSUR, CNRS, Université de Rennes 1, 35000 Rennes, France

$7 \quad{ }^{2}$ Brigham Young University, Department of Plant and Wildlife Sciences, Provo, USA

Emails: lou.barbe@univ-rennes1.fr; andreas.prinzing@univ-rennes1.fr; cendrine.mony@univ-

9

rennes1.fr; benabbo@gmail.com; mathieu.santonja@univ-rennes1.fr; kevin.hoeffner@univ-rennes1.fr;

sarah.guillocheau@univ-rennes1.fr; daniel.cluzeau@univ-rennes1.fr; andre-jean.francez@univrennes1.fr; nathalie.lebris@univ-rennes1.fr; vincent.jung@univ-rennes1.fr

Type of article: Research Article

Abstract word count/Total word count 250/4545, number of figures/tables/appendices 4/0/3

\section{Highlights :}

- Plant-community assembly impacts plant afterlife traits and decomposer communities

- Plant-community assembly drives litter decomposition at a given successional stage

- Effects of traits and decomposers on decomposition mutually cancel out each other

Short title: Community assembly drives litter decomposition

Corresponding author: Lou Barbe (+33 6674406 56)

Authors' contributions: All authors contributed to the conception of the experiment and the data collection. LB analyzed the data, with help of AP, CM and VJ. LB wrote the manuscript, with help of all authors. 


\section{SUMMARY}

Litter decomposition is central to ecosystem functioning and depends, under constant abiotic conditions, on litter quality and decomposer activity. During the assembly of a plant community following disturbance, litter quality is expected to decrease, due to an increasing proportion of resource-conservative species, whereas decomposer activity is expected to increase, due to the establishment of decomposer populations and their response to local vegetation ("Home-Field Advantage", HFA). To date, the combined effect of these processes remains poorly understood. We studied 27 semi-natural grasslands in western France, ranging from 1 to 25 years since last cultivation. We measured the functional composition of plant communities using litter traits (Specific Leaf Area, Leaf Dry Matter Content, C:N ratio, phenolics), characterized the entire community of decomposers (macrofauna, mesofauna, microbes) and performed reciprocal litter transplants to quantify HFA. We found that, overall, decomposition was rapid, and HFA was not evident. While there was substantial amonggrassland variation in decomposition and HFA, neither changed with grassland age. Litter quality and decomposer efficiency also remained, overall, unchanged. However, grassland age determined all measured litter traits, and caused soil microbial C:N ratio to decline. While these changes impacted decomposition individually, together they cancelled out each other, resulting in constant decomposition across the chronosequence. Our results suggest that processes driving decomposition differ during grassland succession, and suggest that HFA may be lower in communities with high litter quality. Moreover, simultaneous assembly processes have opposing, and therefore stabilizing effects on decomposition, possibly explaining the outstanding resilience of primary production in temperate grassland ecosystems.

Key-words: plant-community assembly, decomposers and detritivores, Home-Field Advantage, grasslands, litter decomposition, plant functional traits 


\section{INTRODUCTION}

The decomposition of plant litter is one of the main bottlenecks regulating carbon storage and nutrient cycling in terrestrial ecosystems (Swift and others 1979). Under a given set of abiotic conditions, litter decomposition is controlled by two main biotic parameters and their interaction (Coûteaux and others 1995): litter quality (Cornelissen and others 1999; Makkonen and others 2012), decomposer community (Petersen and Luxton 1982; Bardgett and van der Putten 2014), and response of decomposers to local litter quality (Austin and others 2014; Veen and others 2015). These biotic factors contribute to differences in decomposition among biomes, and among successional stages (e.g., grassland versus forest), however, it remains unclear whether and how they operate during the assembly of a given successional stage. Grasslands are the most widespread successional stage of temperate terrestrial biomes, and the largest terrestrial ecosystems in the globe. Although the successional stage of grasslands is maintained by agricultural practices (grazing or mowing), community assembly processes still operate, from young, species-poor grasslands dominated by the sown species to old grasslands dominated by spontaneous species (i.e. grassland succession, Cramer and others 2008). In grasslands, between 50 and $90 \%$ of plant primary production ends up as litter (Cebrian 1999). In contrast to temperate forest ecosystems, the production of litter in temperate grasslands may be sustained through the year, due to continuous growth and senescence of graminoid species. Consequently, litter decomposition is a central ecosystem process in natural and semi-natural grasslands, providing many ecosystem services, including nutrient mineralization for plant regrowth.

Throughout the assembly of a grassland plant community, litter decomposition might decrease, due to decreasing litter quality of plant species. Litter quality is determined by the digestibility and the nutritional quality of litter for decomposers, which depends on functional traits of plants (Cornelissen and Thompson 1997). For instance, litter quality decreases with 
high phenol content or high C:N ratio (Hättenschwiler and Vitousek 2000; Quested and others 2007; Bakker and others 2011). Along a succession sequence, these functional traits are likely to differ among successional stages, because traits are involved in plant-plant interactions and community assembly (Hättenschwiler and Vitousek 2000; Garnier and others 2004; Violle and others 2009; Barbe and others 2017). Specifically, resource-conservative traits, which cause litter quality to decline (for instance, high C:N or high leaf dry matter content [LDMC]) may only be expressed in late-succession stages, where plant species are already established and competition is high (Wright and others 2004). During the community assembly of a given successional stage, similar mechanisms might occur and plant species present in older communities might display resource-conservative traits rather than resource-acquisitive traits. These dynamics could result in litter quality, and hence litter decomposition, decreasing with grassland community assembly.

The abundance of grassland detritivores and decomposers and their ability to decompose local litter might increase with time because of processes such as adaptation, plasticity, or ecological sorting, thereby increasing litter decomposition. Both detritivore macrofauna (earthworms) and mesofauna (Collembola, Acari and Enchytraeidae) fragment litter, accelerating the mineralization and respiration of carbohydrates by fungi and bacteria (Petersen and Luxton 1982; Coûteaux and others 1995; Bardgett and van der Putten 2014). Many decomposers are largely immobile and have slow population growth rates. At the onset of grassland community assembly, low decomposer abundance might limit litter decomposition, because grasslands might inherit few decomposers from prior land use: the abundance of detritivores and decomposers decreases considerably in row-crop agriculture, which is considered a major anthropogenic disturbance (Ponge and others 2003, 2013; Chauvat and others 2007). Consequently, time might be required to recover decomposer populations, from the same patch or from adjacent patches (Decaëns and others 2008). 
Moreover, decomposer communities are able to adapt to locally-derived litter: the communities sometimes break down litter more efficiently from "Home" compared to other places, with this phenomenon being called Home-Field Advantage (HFA, Freschet and others 2012; Austin and others 2014; Veen and others 2015). This phenomenon occurs due to species sorting or selecting particular genotypes, which increase the decomposition rate of a particular type of litter through time. However, there is mixed evidence about the consistency and prevalence of HFA (Gießelmann and others 2011; Veen and others 2015). Of note, the response of decomposers to litter quality may have a lag time, depending on particular litter traits or decomposer assemblages, and might more likely to occur in plant communities with low litter quality (Milcu and Manning 2011; Veen and others 2018). Overall, the net effect of changes to decomposer abundance and response to litter quality might therefore depend on the duration of the assembly of grassland plant community, and might increase litter decomposition in old grasslands, counteracting the effects of changes to litter quality.

In this study, we investigated how litter traits, decomposer community, and their interactions affect litter decomposition during community assembly using semi-natural grasslands as a model system. We used a 25-years grassland chronosequence to test whether and how litter decomposition changes with grassland age. Specifically, we tested the following hypotheses: (i) grassland age slows down litter decomposition because litter quality declines and, (ii) grassland age accelerates litter decomposition because decomposer abundance increases or HFA emerges or increases. The chronosequence consisted of 27 grasslands in an agricultural landscape in western France (Brittany), ranging from 1 to 25 years since the last crop. We measured four functional traits aggregated at the plant community level; namely, specific leaf area (SLA), LDMC, C:N ratio, and phenolic concentration. We characterized the entire decomposer community (macrofauna, mesofauna and microbes). We performed a reciprocal 
124 litter transplant experiment, to quantify the response of decomposer communities to local 125 litter quality (HFA).

\section{MATERIALS AND METHODS}

\section{Study Site and Grassland Selection}

We carried out the study at the Long Term Ecological Site (LTER) «Zone Atelier Armorique », which is a $150 \mathrm{~km}^{2}$ research area in Brittany, France $\left(48^{\circ} 36^{\prime} \mathrm{N}, 1^{\circ} 32^{\prime} \mathrm{W}\right)$. Row crops and pastureland cover approximately $90 \%$ of the landscape, which is intersected by a well-developed hedgerow network ranging from 50 to 100 m.ha ${ }^{-1}$ (Thomas and others 2016). We used ground-truthed aerial photos, which were taken every year since 1990, to construct a detailed land-use history for all sites, allowing us to determine the time since cultivation for each grassland precisely. Based on this land-use history and verification with grassland owners, we selected 27 grasslands ranging from one to 25 years since last row cropping. The grasslands were similar with respect to the initial species that were sown (Lolium perenne (L.) and Trifolium repens or pratensis) and management practices (annual mowing and extensive grazing, approximately 60 cows for two days once per month). The grasslands were also similar regarding environmental conditions (mesophilic grasslands) and the type of soil (brown soil that drained freely with well-developped organic and mineral horizons). The total soil C:N ratio of parcels, measured on the top $15 \mathrm{~cm}$ of parcels with a $20 \mathrm{~cm}$ diameter stainless steel hand corer, was $13.4 \pm 1.7$. Parcels were 3 ha \pm 1.4 ha.

\section{Characterization of Plant Community and Plant Functional Traits}

We characterized the percentage coverage of plant species in each grassland during spring 2015 using 10 quadrats of $1 \mathrm{~m}^{2}$ that were evenly distributed within the grassland. We identified the most abundant species(i.e. species accounting for $80 \%$ of the total abundance of the community; Pakeman and Quested 2007), which represented from two to five species for 
each grassland (total richness from 8 to 27). For these species, we measured four functional traits related to litter quality; namely, specific leaf area (SLA), leaf dry matter content (LDMC), leaf C:N ratio and leaf phenolic concentration. These traits mainly reflect the physical and chemical properties of the litter (Hättenschwiler and Vitousek 2000; PérezHarguindeguy and others 2000; Santiago 2007; Quested and others 2007). To obtain a representative mean value for each trait from each species, we measured the traits of 10 individuals that were collected from randomly selected grasslands in our experiment. Phenolic concentration was measured colorimetrically, according to the Folin-Ciocalteu colorimetric method (Folin and Denis 1915) modified by Santonja and others (2015), using gallic acid as a standard. A 0.25 g litter sample was dissolved in an aqueous methanol solution, that was shaken for 1-h and then filtered. The filtered extract was mixed with Folin-Ciocalteu reagent, a color-reaction stabilizer $\left(\mathrm{Na}_{2} \mathrm{CO}_{3}\right)$, and distilled water. After 1-h, phenolics concentration was measured at $765 \mathrm{~nm}$ on a spectrophotometer (Thermo Scientific ${ }^{\circledR}$, USA). We measured SLA and LDMC following the standard protocols of Pérez-Harguindeguy and others (2013), and we measured C:N ratio using an elemental analyzer (FLASH EA 1112 Thermo Finnigan, Waltham, Massachusetts, USA). For each grassland, we aggregated the values of species traits to obtain an abundance-weighted mean for each trait (see Appendix Table S1 for species trait values). Correlations between traits (Appendix Table S2), with only two significant correlations being detected among the six trait correlations that we tested for, indicates low multicollinearity among traits.

\section{Characterization of the Decomposer Community}

We sampled detritivore macrofauna (i.e. earthworms) in each grassland during spring 2016, according to the method of Ponge and others (2013) and Cluzeau and others (2012). In brief, three $1 \mathrm{x} 1 \mathrm{~m}$ quadrats were watered three times with $10 \mathrm{l}$ formalin at increasing concentration every $15 \min (0.075,0.075$ and $0.12 \%$ formaldehyde solution), and a soil block (25x25cm and 
$20 \mathrm{~cm}$ depth) was extracted at the end of sampling and hand sorted. Earthworms that were expelled to the surface by the irritant solution, or were recovered during the sorting of the soil block, were collected. Identification was done in the laboratory following the identification key of Cluzeau and others (unpublished, available upon request), based on Bouché (1972). Earthworms were characterized by abundance and biomass (fresh weight) and were grouped into ecological categories: epigeic or anecic - we excluded endogeic earthworms as they do not directly influence decomposition of surface litter (Bouché 1977). Then, we sampled soil detritivore mesofauna using a cylindrical soil corer $(5 \mathrm{~cm}$ diameter $\times 8 \mathrm{~cm}$ depth; three soil cores per grassland on two sampling dates). Mesofauna was extracted from the soil cores using the Tullgren funnel method (Berlese 1905) over a 10-day period. Collected organisms were stored in 95\% ethanol, counted using a binocular scope and separated into three groups: Acari (Oribatids), Collembola and Enchytraeidae. Finally, we measured soil microbial C:N ratio, as a proxy of the composition of the microbial community, illustrating dominance of fungi or dominance of bacteria (Paul and Clark 1996; Van Elsas and others 2006). We measured the microbial $\mathrm{C}: \mathrm{N}$ ratio using the fumigation-extraction method from Brookes and others (1985) and Vance and others (1987). We collected and aggregated 15 soil cores from the top $10 \mathrm{~cm}$ layer for each grassland to obtain a representative soil sample. From this sample, we used a $30 \mathrm{~g}$ soil sample that was passed through a 2-mm sieve, and was then handsorted to remove any visible organic material (plant roots, litter fragments). Before and after fumigation-extraction, we measured microbial C concentration using a Wet Oxidation Total Carbon Analyzer 1010 (OI-Analytical, USA) and microbial N concentration using a continuous flux AutoAnalyzer (measuring total dissolved N, AA3 Bran \& Luebbe, USA). The microbial $\mathrm{C}$ and $\mathrm{N}$ concentrations were obtained by substracting the values obtained before fumigation-extraction from the values obtained after. Microbial C:N ratio was then calculated by dividing microbial C concentration with microbial $\mathrm{N}$ concentration. 
Abiotic parameters such as soil moisture and soil $\mathrm{pH}$ can also affect plant traits, decomposer community and litter decomposition (Coûteaux and others 1995). Thus, we quantified soil moisture and $\mathrm{pH}$ in each grassland during spring 2016 using soil samples from the top $15 \mathrm{~cm}$ layer collected with a $20 \mathrm{~cm}$ diameter stainless steel hand corer. After the manual removal of rocks and roots $>2 \mathrm{~mm}$, soil moisture $(\omega)$ was determined by mass loss at $105^{\circ} \mathrm{C}$ for $24 \mathrm{~h}$ according to the formula: $\omega=\frac{(\mathrm{W}-\mathrm{D})}{\mathrm{D}} \times 100$, where $\mathrm{W}$ is the wet soil mass on the sampling date and $\mathrm{D}$ is the dry soil mass. Soil $\mathrm{pH}$ was determined with a 1:10 soil, de-ionized water suspension, following standard methods (Robertson and others 1999). We also accounted for the local landscape surrounding the selected grasslands, which might influence plant traits and decomposer community. Using the database of historical land-use data, we quantified the percentage of each grassland perimeter that was in contact with grasslands older than 5 years, which are adjacent grasslands that represent a significant source of propagules and fauna for the selected grasslands.

\section{Litter Decomposition and Transplant Experiment}

In each grassland, we collected litter in the fall of 2015 for the 2-5 species accounting for $80 \%$ of total plant abundance. We did not collect stems. For all species, we collected green material for litter as in semi-natural grasslands the main portion of plant material contributing to the litter pool is green material, not senesced litter (due to mowing and grazing, Mazzanti and others 1994; Sanaullah and others 2010). The duration of leaf decomposition is very short for the main grassland species in our experiment (especially Lolium perenne and legumes from the genera Trifolium, see Results for mass losses) such their leaves decompose before achieving complete senescence. Litter was cleaned, air-dried, and placed into 8x8 cm mesh bags. Litterbags had $2 \mathrm{~mm}$ mesh on the upper side to avoid contamination by allochthonous 
litter, and $5 \mathrm{~mm}$ mesh on the lower side to allow numerous detritivores to shuttle between the soil and litter to freely access the litter - during the period of exposure. Litter always remained moist and was never brittle. Litterbags were positioned on bare ground by gently pushing aside grasses (i.e. without removing any plants). Each litterbag contained 1g of litter, that was oven-dried equivalent (air-dry/oven-dry ratio calculated from subsamples that were oven-dried but not exposed to decomposition), and were constructed with the relative proportion of species from the grassland. We constructed 15 litterbags for each grassland, five of which were placed in the original grassland ("Home" decomposition) and 10 of which we randomly placed in 10 other grasslands of the experiment (“Away” decomposition) to measure HFA. We performed decomposition experiments during early spring 2016 and litterbags were collected 10 days later, when they reached 30-60\% mass loss. Mass loss was measured on all 15 samples per grassland after cleaning the litter, and were oven-dried at 65 ${ }^{\circ} \mathrm{C}$ for three days. Mass loss (\%) was calculated as $\left(1-\frac{\mathrm{m} 1}{\mathrm{~m} 0}\right) \times 100$, where $\mathrm{m}_{0}$ is the initial oven-dried equivalent dry weight and $\mathrm{m}_{1}$ is the oven-dry weight at collection.

We calculated HFA, litter quality and soil ability (i.e. abiotic conditions and decomposer efficiency) for each grassland by running the Decomposer Ability Regression Test (Keiser and others 2014) using SAS University Edition (SAS Institute, Cary, NC). This analysis disentangles, for a given mass loss, the effects of HFA, litter quality, and soil ability, estimated respectively by the parameters $\eta_{h}, \beta_{l}$ and $\gamma_{s}$ in the following equation:

$$
Y_{i}=\alpha+\sum_{i=1}^{N} \beta_{l} \text { Litter }_{l_{i}}+\sum_{s=1}^{M} \gamma_{S^{S o i l}} s_{i}+\sum_{h=1}^{K} \eta_{h} \text { Home }_{h_{i}}+\varepsilon_{i}
$$

where $\mathrm{Y}_{\mathrm{i}}$ is the decomposition of obervation $\mathrm{i}$, and Litter ${ }_{\mathrm{l}}$, Soil $\mathrm{s}_{\mathrm{s}}$, and $\mathrm{Home}_{\mathrm{h}}$ are dummy variables that equal 1 or 0 , respectively, depending on the presence or absence of the litter mixture (from the litter mixture 1 to $\mathrm{N}$ ), soil community (from soil community 1 to $\mathrm{M}$ ) and 
home combination (from home combinations 1 to K). The average decomposition in the data set is $\alpha$ (i.e. the intercept of the model) and $\varepsilon$ is the error term. $\beta_{\mathrm{l}}$ and $\gamma_{\mathrm{s}}$ were restricted to prevent perfect collinearity. The value of a given parameter that was estimated $\left(\eta_{\mathrm{h}}, \beta_{\mathrm{l}}\right.$ and $\left.\gamma_{\mathrm{s}}\right)$ indicated, as a single percentage per grassland, the difference to the mean decomposition of 249 the dataset due to this parameter. These single parameters per grassland will be further 250 correlated with grassland age, because there is no variation of age within grasslands.

\section{1}

To explore whether and how HFA is driven by litter traits and detritivore and decomposer descriptors, we calculated the HFA for the five "Home” replicates of each grassland, because plant traits vary within grasslands (similar to Veen and others 2018). We used the following equations (Gießelmann and others 2011, Pérez and others 2013):

(1) $\mathrm{HFA}_{\mathrm{a} 1}=\mathrm{HDD}_{\mathrm{a} 1}-\mathrm{ADD}_{\mathrm{a}}-\mathrm{H}$

(2) $\mathrm{HDD}_{\mathrm{a} 1}=\Sigma\left(\mathrm{D}_{\mathrm{a} 1 \mathrm{a}}-\mathrm{D}_{\mathrm{ia}}\right)$

(3) $\mathrm{ADD}_{\mathrm{a}}=\Sigma\left(\mathrm{D}_{\mathrm{ai}}-\mathrm{D}_{\mathrm{ii}}\right)$

(4) $\mathrm{H}=\sum \mathrm{HDD} /(\mathrm{n}-1)$

HFA $_{a 1}$ represents the Home-Field Advantage for litter replicate 1 of grassland a. Positive values indicated, as a percentage, faster home decomposition than expected, while negative values indicated slower home decomposition than expected. $\mathrm{HDD}_{\mathrm{a} 1}$ represents the Home Decomposition Difference for litter replicate 1 from grassland a. This value was the sum of the differences between the decomposition of this litter in its original grassland a $\left(D_{a 1 a}\right)$ and the decomposition in this grassland of litters from other grasslands $\mathrm{i}\left(\mathrm{D}_{\mathrm{ia}}\right)$. $A \mathrm{AD}_{\mathrm{a}}$ represents the Away Decomposition Difference for grassland a. This value was the sum of the differences between the decomposition of litter from grassland a in other grasslands $i$ and the home decomposition of grasslands i. H represents the sum of all HDD for all litters divided by amount of litters minus one. Overall, we quantified HFA per litter bag, as established in the 
literature (see above), however, we stress that quantification per grassland (i.e. using means) led to very similar results and are hence not presented.

To explore the role of litters traits and decomposer community on litter decomposition per se, we calculated three mass loss values for each grassland, by averaging mass loss within the three treatment types: home litter at home, home litter away, and away litter at home. This approach allowed us to test for the numerous effects of plant traits and decomposer communities, that may vary within a grassland (similar to Veen et al. 2018). Analyses based on all values within grasslands led to the same conclusions (except that explained variance was slightly smaller and $P$-values were even more significant, due to the larger sample) and are therefore not presented.

\section{Statistical Analyses}

Before all the statistical tests, we center-scaled all variables (i.e. transformed variables by subtracting their mean and dividing by their standard deviation) to permit comparisons of regression coefficients within and among models. We used multiple ordinary least square (OLS) regression models to test the effect of grassland age on plant functional traits (SLA, LDMC, C:N ratio, phenolics) and decomposer community (soil microbial C:N ratio, abundance and biomass of epigeic earthworms and anecic earthworms, and abundance of Acari, Collembola and Enchytraeidae), accounting for abiotic parameters and local landscape (soil moisture, soil $\mathrm{pH}$ and percentage of adjacent grasslands). We used simple OLS regression models to test the effect of grassland age on HFA, soil ability, litter quality, and litter mass loss. We used multiple OLS regression models to test the effect of plant functional traits and decomposer community on litter mass loss and HFA (as calculated in Gießelmann and others 2011, Pérez and others 2013) also accounting for abiotic parameters, local landscape and grassland age. Of note, in the model explaining mass loss we also included the 
transplantation treatment (home litter at home, home litter away, away litter at home), however, this factor was not significant and we do not present the results. To summarize the results of the individual regression analyses, we conducted a path analysis (Wright 1934), which allowed us to visualize the strength of the indirect effects of grassland age on litter mass loss and HFA, which were effects mediated by plant functional traits and decomposer community. For each indirect effect, we calculated a compound path by multiplying: (i) the standardized regression coefficient from the model that related grassland age to plant functional traits or decomposer community with (ii) the standardized regression coefficient from the model that related plant functional traits or decomposer community to litter mass loss. Finally, we compared, for litter mass loss and HFA, the sum of the indirect effects of grassland age with the single overall effect of grassland age. We graphically examined residuals using probability plots and predicted versus residual plots, indicating that all residual distributions fulfilled the assumption of normality and homogeneity. All statistical analyses were performed with R 3.0.3 (R Development Core Team 2016).

\section{RESULTS}

\section{Plant Functional Traits and Decomposer Community Depend on Grassland Age}

We observed large differences in the functional traits of the plant community and in the composition of the decomposer community among entire grasslands. Grassland age strongly explained all functional traits of the plant community (simple regression analyses, Figure 1). Specifically, age increased leaf C:N ratio $\left(\mathrm{F}_{18}=11.07, P=7.10^{-4}\right.$, adj- $\left.\mathrm{R}^{2}=0.50\right)$, leaf phenolic concentration $\left(\mathrm{F}_{18}=4.19, P=0.03\right.$, adj- $\left.\mathrm{R}^{2}=0.24\right)$, and SLA $\left(\mathrm{F}_{19}=3.71, P=0.04, \mathrm{R}^{2}=0.20\right)$, while it decreased LDMC $\left(\mathrm{F}_{25}=31.64, P=7.10^{-6}\right.$, adj- $\left.\mathrm{R}^{2}=0.52\right)$. Old grasslands hence harbored a plant community with mainly thin, moist leaves; however, these leaves contained lower nitrogen concentration and higher phenolic content. Grassland age also increased soil 
microbial C: $\mathrm{N}$ ratio $\left(\mathrm{F}_{20}=5.32, P=0.03, \mathrm{R}^{2}=0.17\right.$, Figure 1$)$, as well as the abundance of Acari ( $F_{23}=9.20, P=6.10^{-3}, R^{2}=0.25$, Figure 1$)$. Earthworm abundance, as well as the abundance of Collembola and Enchytraeidae, was not associated with grassland age; however, the percentage of adjacent grasslands increased the abundance of anecic earthworms (Figure S1). Despite multiple relationships between age and either litter traits or decomposer community, we found one significant correlation between litter traits and detritivore and decomposer community (Acari vs LDMC, $\mathrm{r}=-0.54, \mathrm{P}<0.05$, see Table S2).

Litter Decomposition and Home-Field Advantage Differ Among Grasslands and Depend on Plant Functional Traits and the Decomposer Community

We observed large among-grassland differences in litter mass loss and HFA (Figure S2). Overall, across all of the litters in our experiment, we did not observe a positive mean HFA (no significant difference from a mean of $0, \mathrm{t}=1.41 \mathrm{df}=133, P=0.16$ ). Grassland age did not directly influence litter mass loss $\left(\mathrm{F}_{25}=0.29, P=0.60\right.$, Figure 2$)$, HFA $\left(\mathrm{F}_{25}=0.41, P=0.53\right.$, Figure 2), soil ability $\left(\mathrm{F}_{25}=0.71, \mathrm{P}=0.41\right.$, Figure 2$)$ nor litter quality $\left(\mathrm{F}_{25}=0.22, \mathrm{P}=0.4\right.$, Figure 2). However, several plant functional traits and the soil microbial $\mathrm{C}: \mathrm{N}$ ratio, related to grassland age, strongly explained litter mass loss $\left(\mathrm{F}_{56}=12.43, P=7.10^{-9}\right.$, adj- $\mathrm{R}^{2}=0.53$, Figure 3): the leaf C:N ratio decreased litter mass loss, as did LDMC and SLA (Figure 3). Decrease in soil microbial C:N was associated with decrease in litter mass loss (Figure 3). Moreover, soil moisture decreased litter mass loss (Figure S3). None of the plant functional traits influenced HFA, but HFA increased when anecic earthworms were more abundant (Figure $\mathrm{S} 1, \mathrm{~F}_{101}=6.37, P=0.044$, semi-partial $\mathrm{R}^{2}=0.06$ ) and when soil moisture was low (Figure S3, $\mathrm{F}_{101}=6.37, P=0.013$, semi-partial $\mathrm{R}^{2}=0.03$ ). We also note that, when explaining litter mass loss by functional traits and decomposer community, a positive, direct effect of grassland age on litter mass loss was detected after removal of all other significant effects (Figure S4). Finally, as plant functional traits and soil microbial C:N were influenced by grassland age, we 
obtained the following indirect effects of grassland age on litter mass loss (Figure S4): -0.42 via leaf C:N ratio, -0.26 via SLA, 0.53 via LDMC, -0.15 via the soil microbial C:N ratio and 0.22 via an unmeasured parameter. The sum of all indirect effects of grassland age on litter mass loss was -0.08 , indicating no significant total effect, which was consistent with the lack of an overall effect of grassland age on litter mass loss that we initially observed (Figure 2).

\section{DISCUSSION}

Grassland age influenced all measured functional traits of the plant community, as well as the soil microbial C:N ratio. These changes, in turn, impacted litter mass loss, but they cancelled each other out, resulting in constant litter decomposition across the chronosequence. Litter overall mass loss, litter quality (i.e. litter decomposability), decomposer efficiency, and HFA did not change with grassland age.

Plant Functional Traits Change with Age, but not towards Resource-Conservatism

The four functional traits that we measured on plant communities strongly responded to grassland age. Specifically, the plant communities of old grasslands displayed a higher leaf C:N ratio and phenolic concentration, along with higher SLA and lower LDMC. Thus, grassland assembly favored resource-conservative trait values as much as resource-acquisitive trait values. This result contrasted with what we expected from other studies (Wright and others 2004; Quested and others 2007). These changes in functional traits were probably due to plant turnover during grassland assembly, with new species establishing and dominating initial species that had higher $\mathrm{C}: \mathrm{N}$ and phenolic concentration (for instance, Ranunculus repens or Dactylis glomerata, Figure S5). These characteristics might enhance the resistance of these new species against herbivores (Bernays and others 1989). Moreover, high SLA and low LDMC might facilitate high resource acquisition and hence regrowth to compensate for herbivory (Briske 1996). This observed plant succession during grassland assembly might be 
attributed to the immigration of new plant species from the surrounding landscape or by the germination of seeds already present in the soil seed bank. Overall, these results show that shifts to plant afterlife traits arise during the assembly of a successional stage (i.e. grasslands), not only across successional stages, for example after grassland abandonment (Kahmen and Poschlod 2004; Quested and others 2007).

\section{Offsetting Effects of Plant Traits on Litter Decomposition}

Individually, each of these changes to plant traits (except changes to phenolics) influenced litter decomposition, but they did not reduce litter decomposition, which remained unchanged with grassland age overall: an increase in SLA and C:N ratio decreased litter decomposition, but this was compensated by a decrease in LDMC which increased litter decomposition. While the effects of the C:N ratio and LDMC are consistent with the literature (Bakker and others 2011; Pakeman and others 2011), the negative effect of SLA on mass loss was inconsistent with the literature (Santiago 2007; Makkonen and others 2012). However, studies on SLA usually focus on SLA values distinctly smaller than ours. This negative relationship might be explained by the higher compaction of litter with very thin leaves (i.e. high SLA), slowing down the colonization of litters by detritivores and decomposers. Alternatively, compensatory feeding (i.e. enhanced consumption rate on poor-quality litter to ensure sufficient resource assimilation to meet metabolic needs; Gessner and others 2010) on litter with low SLA might also explain the negative effect of SLA on mass loss. Finally, the lack of influence of leaf phenolic concentration on decomposition was possibly due to the lower leaf phenolic concentration of grassland plants compared to other systems (Hättenschwiler and Vitousek 2000) which might have prevented the effects from being detectable. Taken together, our results suggest, contrary to what we expected, that community assembly processes result in similar litter quality during grassland succession, likely due to compensatory effects on afterlife traits and litter quality. 
392 Only some components of decomposer communities responded to grassland age, partially 393 supporting our predictions. Anecic and epigeic earthworms (macrofauna) did not respond to 394 grassland age; however, the abundance of anecic earthworms increased in grasslands that shared more edges with other grasslands, suggesting the immigration of anecics from the surrounding landscape, consistently with their high dispersal ability (Caro and others 2013).

Considering mesofauna and microbes, we observed two shifts: the abundance of Oribatids (Acari, detritivore mesofauna) increased with grassland age, as did the soil microbial C:N ratio. The increase in the abundance of Oribatids might be attributed to the recovery of populations of these soil organisms after land-use turnover and the disruptive agricultural practices before the sowing of grasslands (Hülsmann and Wolters 1998). Recovery might be permitted by the immigration of new species from an adjacent landscape, or by the demographic development of the remaining initial species. Finally, the increase in soil microbial C: $\mathrm{N}$ ratio with grassland age might be attributed to a reduction in mineral $\mathrm{N}$ input after cropping, ultimately causing the depletion of microbial N (Wardle 1992).

\section{Strong Functional Redundancy of Detritivores and Decomposers in Grassland Ecosystems?}

Unexpectedly, the abundance of macrofauna and mesofauna did not influence decomposition (Milcu and others 2008), suggesting that microbial and fungal decomposition were not limited by the fragmentation of leaves. The only decomposer-mediated effect we could identify was the increase in soil microbial C:N ratio that was associated with decreasing litter mass loss. Possibly, high soil microbial C:N also reflected a change in the composition of the microbial community, from a dominance of bacteria to a dominance of fungi (Paul and Clark 1996; Van Elsas and others 2006), which might be less efficient at decomposing labile litter (Santonja and others 2018). This slight, microbial C:N-mediated, decrease in litter mass loss was 
probably compensated for by a slight increase of litter mass loss due to a statistically direct effect of grassland age in the full model; this effect was necessarily that of age on one or several parameters that we did not measure (and it may be a biologically indirect effect, like the effects of plant traits and decomposers that we observed), and it explains why soil ability, which represents decomposer efficiency and abiotic conditions, remained globally similar among grasslands. Overall, the lack of relationships between detritivores and decomposers with decomposition might be attributed to the high functional redundancy of these groups for decomposing grassland litter (Gessner and others 2010). Despite variation in the abundance of detritivores and decomposers in our grasslands, there was no effect of any particular group on decomposition. Given the high decomposability of litter in grasslands, the effects of detritivores and decomposers on decomposition might be particularly redundant, with this feature being very stable across time.

\section{No Impact of Grassland Age on Home-Field Advantage, Due to High Litter Decomposability?}

We found, overall, a low HFA, with a substantial variation across grasslands. We found only one significant relationship between the numerous plant traits and detritivores and decomposers that we sampled, not indicating ecological sorting or abundance shifts of detritivores and decomposers in response to litter traits. Overall, we found no relationship between grassland age and HFA: grassland age did not influence HFA, nor did plant functional traits and soil microbial $\mathrm{C}: \mathrm{N}$ ratio. Besides, litter decomposition rates were very high in our experiment, resulting from the very high decomposability of the green litter of graminoids and Trifolium sp. (Sanaullah and others 2010 for similar decomposition rates). High decomposition also resulted from the humid and relatively warm, frost-free winter in the study region which increases decomposer activity (this rapidity is also illustrated by the absence of a distinct litter layer in the grasslands). Therefore, our results support that strong HFA may only arise when home litter is very recalcitrant or very dissimilar to other litter 
(Milcu and Manning 2011; Li and others 2017; Lu and others 2017; Palozzi and Lindo 2018;

Hoyos-Santillan and others 2018). Only increased abundance of anecic earthworms triggered some HFA. This interesting phenomenon might reflect, for instance, the response of digestive enzymes of anecic earthworms to local litter (Eisenhauer and others 2012): the digestive metabolism of earthworms could acclimate to home litter, and then secrete more enzymes that are adapted to home litter, which would increase digestion and hence litter consumption. Alternatively, in their permanent galleries, the mucus of anecic earthworms might have been a durable, high quality substrate for decomposer microorganisms, giving them time to adapt to local litter, ultimately triggering HFA. Finally, high soil moisture triggered a slight HomeField Disadvantage. This might be due to waterlogging triggering anoxy in the top soil, decreasing bacterial and fungal activity (thus decreasing mass loss per se) especially in soft, easily hydratable and compactable litters produced within the home environment. Overall, these results show that grassland maturation did not drive HFA, and that HFA might only occur when litter is very recalcitrant or dissimilar, which was not the case in our system. Hence, HFA did not require experience of local decomposers with local plants, but rather environments favorable for macrofauna and aerobic decomposition. Earthworms might have a role in this process, despite being quite generalist organisms, with microbes not being the only biotic drivers of HFA (Freschet and others 2012; Austin and others 2014). Further studies, including the sampling of detritivore and decomposer traits, and including the exclusion of fauna, are required to elucidate the precise role of fauna and microbes on HFA.

\section{CONCLUSIONS}

We found that community assembly maintained similar litter decomposition along a 25-years chronosequence, and that HFA was not associated with plant community assembly or age. HFA was quite low and was only associated with the macrofauna community and soil moisture, which were not related to grassland age. However, our results showed that several 
plant functional traits and the soil microbial C:N ratio changed during community assembly.

466 In turn, these changes acted on decomposition, but cancelled out each other, resulting in the

467 same decomposition rate across succession. These results also suggest that in temperate

468

469

470

471

472

473

474

475

476

477

478

479

480

481

482

483

484

485

grassland ecosystems, where decomposition is very fast, numerous and important changes in plant and decomposer communities lead to the same levels of ecosystem functions, possibly explaining the outstanding resilience of many grassland ecosystems despite being often a transitional stage.

\section{ACKNOWLEDGEMENTS}

We thank Aurélien Pierre for measuring the soil microbial C:N ratio, and we acknowledge Albin Fertil, Daniel Cylly, André Bastin, Valentin Blanchard, Romain Georges, Olivier Jambon, Jérémy Guy, Nathan Vannier and Stéphanie Llopis for help with sampling earthworms. We are very grateful to Mathilde Le Moing for earthworm identification. We thank Jean-Sébastien Pierre for helping with the SAS statistical analyses. The work benefited from the support of the LTER site "ZA Armorique". 
488

489

490

491

492

493

494

495

496

497

498

499

500

501

502

503

504

505

506

Austin AT, Vivanco L, González-Arzac A, Pérez LI. 2014. There’s no place like home? An exploration of the mechanisms behind plant litter-decomposer affinity in terrestrial ecosystems. New Phytologist 204: 307-314.

Bakker MA, Carreño-Rocabado G, Poorter L. 2011. Leaf economics traits predict litter decomposition of tropical plants and differ among land use types: Leaf economics traits and decomposition. Functional Ecology 25: 473-483.

Barbe L, Jung V, Prinzing A, Bittebiere A-K, Butenschoen O, Mony C. 2017. Functionally dissimilar neighbors accelerate litter decomposition in two grass species. New Phytologist 214: 1092-1102.

Bardgett RD, van der Putten WH. 2014. Belowground biodiversity and ecosystem functioning. Nature 515: 505-511.

Berlese A. 1905. Apparicchio per raccogliere presto ed in gran numero di piccolo artropodi. Redia 2: 85-89.

Bernays EA, Driver GC, Bilgener M. 1989. Herbivores and plant tannins. Advances in ecological research 19: 263-302.

Bouché, MB. 1972. Lombriciens de France: écologie et systématique, Paris.

Bouché MB. 1977. Stratégies lombriciennes. Ecological Bulletins 25: 122-132.

Briske DD. 1996. Strategies of plant survival in grazed systems: a functional interpretation.

The ecology and management of grazing systems 37-67. 
Brookes PC, Landman A, Pruden G, Jenkinson DS. 1985. Chloroform fumigation and the release of soil nitrogen: a rapid direct extraction method to measure microbial biomass nitrogen in soil. Soil Biology and Biochemistry 17: 837-842.

Caro G, Decaëns T, Lecarpentier C, Mathieu J. 2013. Are dispersal behaviours of earthworms related to their functional group? Soil Biology and Biochemistry 58: 181-187.

Cebrian J. 1999. Patterns in the fate of production in plant communities. The American Naturalist 154: 449-468.

Chauvat M, Wolters V, Dauber J. 2007. Response of collembolan communities to land-use change and grassland succession. Ecography 30: 183-192.

Cluzeau D, Guernion M, Chaussod R, Martin-Laurent F, Villenave C, Cortet J, RuizCamacho N, Pernin C, Mateille T, Philippot L, Bellido A, Rougé L, Arrouays D, Bispo A, Pérès G. 2012. Integration of biodiversity in soil quality monitoring: Baselines for microbial and soil fauna parameters for different land-use types. European Journal of Soil Biology 49: 63-72.

Cornelissen JHC, Pérez-Harguindeguy N, Diaz S, Grime JP, Marzano B, Cabido M, Vendramini F, Cerabolini B. 1999. Leaf structure and defence control litter decomposition rate across species and life forms in regional floras on two continents. New Phytologist 143: 191-200.

Cornelissen JHC, Thompson K. 1997. Functional leaf attributes predict litter decomposition rate in herbaceous plants. New Phytologist 135: 109-114.

Coûteaux M-M, Bottner P, Berg B. 1995. Litter decomposition, climate and litter quality. Trends in Ecology \& Evolution 10: 63-66. 
Cramer VA, Hobbs RJ, Standish RJ. 2008. What's new about old fields? Land abandonment and ecosystem assembly. Trends in Ecology \& Evolution 23: 104-112.

Decaëns T, Margerie P, Aubert M, Hedde M, Bureau F. 2008. Assembly rules within earthworm communities in North-Western France-A regional analysis. Applied Soil Ecology 39: 321-335.

Eisenhauer N, Reich PB, Isbell F. 2012. Decomposer diversity and identity influence plant diversity effects on ecosystem functioning. Ecology 93: 2227-2240.

Folin O, Denis W. 1915. A colorimetric method for the determination of phenols (and phenol derivatives) in urine. Journal of Biological Chemistry 22: 305-308.

Freschet GT, Aerts R, Cornelissen JHC. 2012. Multiple mechanisms for trait effects on litter decomposition: moving beyond home-field advantage with a new hypothesis: Substratematrix quality interactions in decay. Journal of Ecology 100: 619-630.

Garnier E, Cortez J, Billès G, Navas M-L, Roumet C, Debussche M, Laurent G, Blanchard A, Aubry D, Bellmann A, Neill C, Toussaint J-P. 2004. Plant functional markers capture ecosystem properties during secondary succession. Ecology 85: 2630-2637.

Gessner MO, Swan CM, Dang CK, McKie BG, Bardgett RD, Wall DH, Hättenschwiler S. 2010. Diversity meets decomposition. Trends in ecology \& evolution 25: 372-380.

Gießelmann UC, Martins KG, Brändle M, Schädler M, Marques R, Brandl R. 2011. Lack of home-field advantage in the decomposition of leaf litter in the Atlantic Rainforest of Brazil. Applied Soil Ecology 49: 5-10.

Güsewell S, Gessner MO. 2009. N : P ratios influence litter decomposition and colonization by fungi and bacteria in microcosms. Functional Ecology 23: 211-219. 
551 Hättenschwiler S, Vitousek PM. 2000. The role of polyphenols in terrestrial ecosystem 552 nutrient cycling. Trends in Ecology \& Evolution 15: 238-243.

553 Hülsmann A, Wolters V. 1998. The effects of different tillage practices on soil mites, with 554 particular reference to Oribatida. Applied Soil Ecology 9: 327-332.

555 Hoyos-Santillan J, Lomax BH, Turner BL, Sjögersten S. 2018. Nutrient limitation or home 556 field advantage: Does microbial community adaptation overcome nutrient limitation of litter 557 decomposition in a tropical peatland? Journal of Ecology 106: 1558-1569.

558 Kahmen S, Poschlod P. 2004. Plant functional trait responses to grassland succession over 25 559 years. Journal of Vegetation Science 15: 21-32.

560 Keiser AD, Keiser DA, Strickland MS, Bradford MA. 2014. Disentangling the mechanisms 561 underlying functional differences among decomposer communities. Journal of Ecology 102: $562 \quad 603-609$.

563 Li YB, Li Q, Yang JJ, Lü XT, Liang WJ, Han XG, Bezemer TM. 2017. Home-field 564 advantages of litter decomposition increase with increasing $\mathrm{N}$ deposition rates: a litter and soil 565 perspective. Functional Ecology 31: 1792-1801.

566 Lu W, Liu N, Zhang Y, Zhou J, Guo Y, Yang X. 2017. Impact of vegetation community on 567 litter decomposition: Evidence from a reciprocal transplant study with ${ }^{13} \mathrm{C}$ labeled plant litter. 568 Soil Biology and Biochemistry 112: 248-257.

569 Makkonen M, Berg MP, Handa IT, Hättenschwiler S, van Ruijven J, van Bodegom PM, Aerts 570 R. 2012. Highly consistent effects of plant litter identity and functional traits on 571 decomposition across a latitudinal gradient. Ecology Letters 15: 1033-1041. 
572 Mazzanti A, Lemaire G, Gastal F. 1994. The effect of nitrogen fertilization upon the herbage

573 production of tall fescue swards continuously grazed with sheep. II-herbage consumption.

574 Grass and Forage Science 49: 352-359.

575 Milcu A, Manning P. 2011. All size classes of soil fauna and litter quality control the 576 acceleration of litter decay in its home environment. Oikos 120: 1366-1370.

577 Milcu A, Partsch S, Scherber C, Weisser WW, Scheu S. 2008. Earthworms and legumes 578 control litter decomposition in a plant diversity gradient. Ecology 89: 1872-1882.

579 Pakeman RJ, Eastwood A, Scobie A. 2011. Leaf dry matter content as a predictor of grassland 580 litter decomposition: a test of the "mass ratio hypothesis". Plant and Soil 342: 49-57.

581 Pakeman RJ, Quested HM. 2007. Sampling plant functional traits: What proportion of the 582 species need to be measured? Applied Vegetation Science 10: 91-96.

583 Palozzi JE, Lindo Z. 2018. Are leaf litter and microbes team players? Interpreting home-field 584 advantage decomposition dynamics. Soil Biology and Biochemistry 124: 189-198.

585 Paul, EA, Clark FE. 1996. Soil Microbiology and Biochemistry. Academic Press, California. 586 340p.

587 Perez G, Aubert M, Decaëns T, Trap J, Chauvat M. 2013. Home-field advantage: a matter of 588 interaction between litter biochemistry and decomposer biota. Soil Biology and Biochemistry 589 67: 245-254.

590 Pérez-Harguindeguy N, Diaz S, Cornelissen JHC, Vendramini F, Cabido M, Castellanos A. 591 2000. Chemistry and toughness predict leaf litter decomposition rates over wide spectrum of 592 functional types and taxa in central Argentina. Plant and Soil 218: 21-30. 
Pérez-Harguindeguy N, Díaz S, Garnier E, Lavorel S, Poorter H, Jaureguiberry P, Bret-Harte MS, Cornwell WK, Craine JM, Gurvich DE, Urcelay C, Veneklaas EJ, Reich PB, Poorter L, Wright IJ, Ray P, Enrico L, Pausas JG, de Vos AC, Buchmann N, Funes G, Quétier F, Hodgson JG, Thompson K, Morgan HD, ter Steege H, Sack L, Blonder B, Poschlod P, Vaieretti MV, Conti G, Staver AC, Aquino S, Cornelissen JHC. 2013. New handbook for standardised measurement of plant functional traits worldwide. Australian Journal of Botan, 61: 167-234.

Petersen H, Luxton M. 1982. A Comparative Analysis of Soil Fauna Populations and Their Role in Decomposition Processes. Oikos 39: 288-388.

Ponge J-F, Gillet S, Dubs F, Fedoroff E, Haese L, Sousa JP, Lavelle P. 2003. Collembolan communities as bioindicators of land use intensification. Soil Biology and Biochemistry 35: 813-826.

Ponge J-F, Pérès G, Guernion M, Ruiz-Camacho N, Cortet J, Pernin C, Villenave C, Chaussod R, Martin-Laurent F, Bispo A, Cluzeau D. 2013. The impact of agricultural practices on soil biota: A regional study. Soil Biology and Biochemistry 67: 271-284.

Quested H, Eriksson O, Fortunel C, Garnier E. 2007. Plant traits relate to whole-community litter quality and decomposition following land use change. Functional Ecology 21: 10161026.

R Core Team (2016) R: A language and environment for statistical computing. R Foundation for Statistical Computing, Vienna, Austria. URL https://www.R-project.org/.

Robertson GP. 1999. Standard soil methods for long-term ecological research (Vol. 2), Oxford University Press. 
Sanaullah M, Chabbi A, Lemaire G, Charrier X, Rumpel C. 2010. How does plant leaf senescence of grassland species influence decomposition kinetics and litter compounds dynamics? Nutrient Cycling in Agroecosystems 88: 159-171.

Santiago LS. 2007. Extending the leaf economics spectrum to decomposition: evidence from a tropical forest. Ecology 88: 1126-1131.

Santonja M, Fernandez C, Gauquelin T, Baldy V. 2015. Climate change effects on litter decomposition: intensive drought leads to a strong decrease of litter mixture interactions. Plant and Soil 393: 69-82.

Santonja M, Foucault Q, Rancon A, Gauquelin T, Fernandez C, Baldy V, Mirleau P. 2018. Contrasting responses of bacterial and fungal communities to plant litter diversity in a Mediterranean oak forest. Soil Biology and Biochemistry 125: 27-36.

Swift MJ, Heal OW, Anderson JM. 1979. Decomposition in terrestrial ecosystems (Vol. 5), Univ of California Press.

Thomas Z, Abbott BW, Troccaz O, Baudry J, Pinay G. 2016. Proximate and ultimate controls on carbon and nutrient dynamics of small agricultural catchments. Biogeosciences 13: 18631875.

Vance ED, Brookes PC, Jenkinson DS. 1987. An extraction method for measuring soil microbial biomass C. Soil Biology and Biochemistry 19: 703-707.

Van Elsas JD, Trevors JT, Jansson JK, Nannipieri P. 2006. Modern soil microbiology. CRc Press, Florida. 683p.

Veen GFC, Freschet GT, Ordonez A, Wardle DA. 2015. Litter quality and environmental controls of home-field advantage effects on litter decomposition. Oikos 124: 187-195. 
Veen GFC, Keiser AD, van der Putten WH, Wardle DA. 2018. Variation in home-field

638 advantage and ability in leaf litter decomposition across successional gradients. Functional 639 Ecology 32 :1563-1574.

640

641

642

643

644

645

646

647

648

649

650

651

652

653

654

655

656

657

Violle C, Garnier E, Lecoeur J, Roumet C, Podeur C, Blanchard A, Navas M-L. 2009. Competition, traits and resource depletion in plant communities. Oecologia 160: 747-755.

Wardle DA. 1992. A comparative assessment of factors which influence microbial biomass carbon and nitrogen levels in soil. Biological reviews 67: 321-358.

Wright IJ, Reich PB, Westoby M, Ackerly DD, Baruch Z, Bongers F, Cavender-Bares J, Chapin T, Cornelissen JHC, Diemer M, Flexas J, Garnier E, Groom PK, Gulias J, Hikosaka K, Lamont BB, Lee T, Lee W, Lusk C, Midgley JJ, Navas M-L, Niinemets Ü, Oleksyn J, Osada N, Poorter H, Poot P, Prior L, Pyankov VI, Roumet C, Thomas SC, Tjoelker MG, Veneklass EJ, Villar R. 2004. The worldwide leaf economics spectrum. Nature 428: 821-827.

Wright S. 1934. The method of path coefficients. The Annals of Mathematical Statistics 5: $161-215$. 


\section{Figure captions}

659 Figure 1. Grassland age significantly influenced all aggregated functional traits of the plant community (phenolics, leaf C:N ratio, Leaf Dry Matter Content, and Specific Leaf Area) as

661

662

663

664

665

666

667

668

669

670

671

672 well as the abundance of soil Acari (mesofauna) and soil microbial C:N ratio. Green points represent plant trait values, orange points represent values of decomposer and detritivore indicators. See Results for all model parameters.

Figure 2. Grassland age did not influence Home-Field Advantage (HFA), soil ability (illustrating soil conditions and decomposer efficiency), litter quality (i.e. litter decomposability) nor litter overall mass loss (calculated as the mean per grassland across all litters). See Material and Methods for the transplantation treatment and calculations.

Figure 3. Three aggregated functional traits of plant community and soil microbial C:N ratio decreased litter mass loss. Each graph presents partial residuals, so accounts for the simultaneous effect of the other variables in the model. SP-R ${ }^{2}$ represents semi-partial residuals. Green points represent plant trait values, and orange points represent values of decomposer and detritivore indicators. The three data points per grassland are the mean of the three treatments (home litter exposed at home, home litter exposed away, and away litter exposed at home; the factor containing these treatments did not signifcantly interact with age in the statistical model explaining mass loss). See Material and Methods for the transplantation treatment and calculations, and Results for all model parameters. 
682
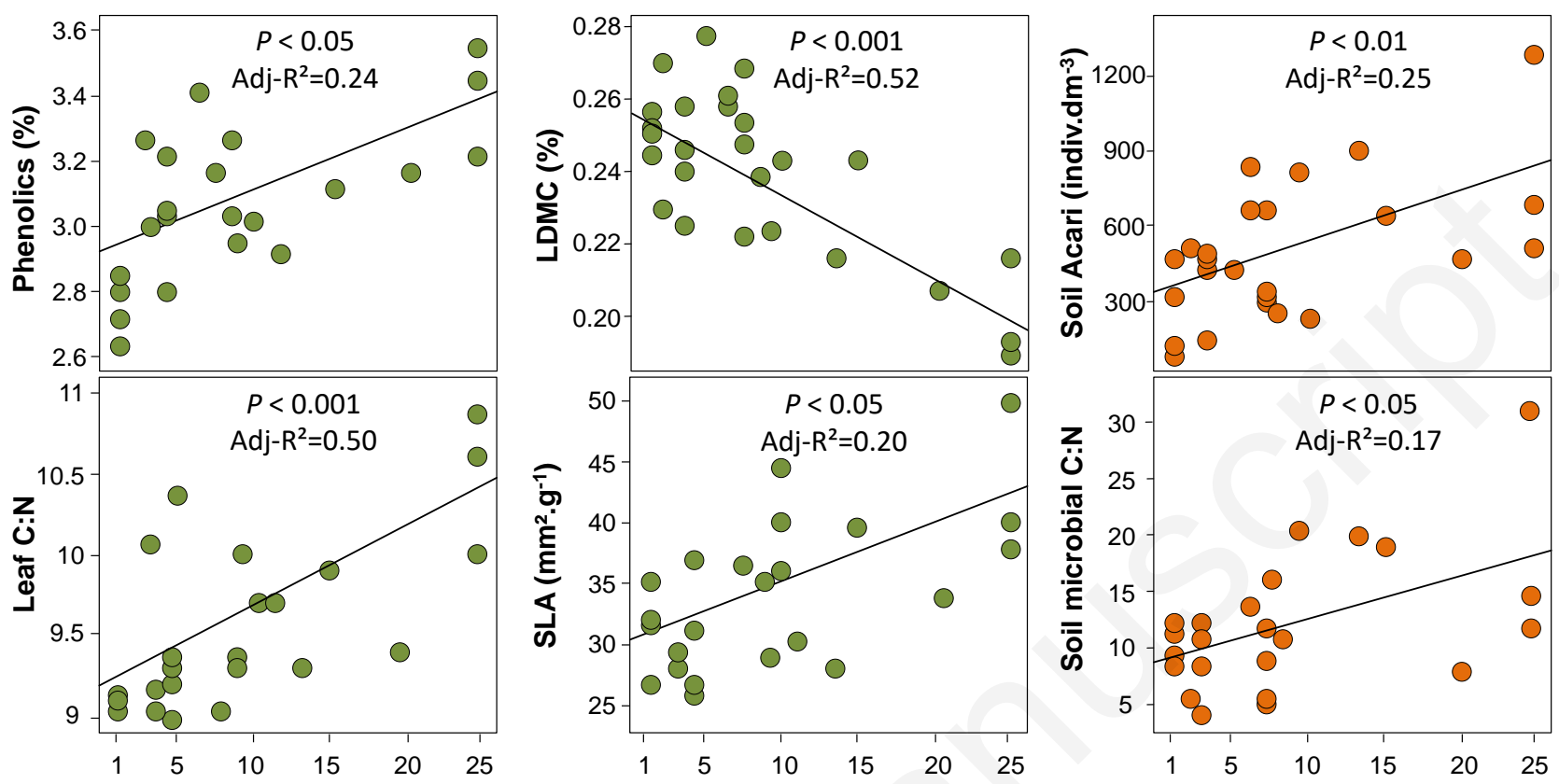

683

Grassland age (years)

Figure 1. 

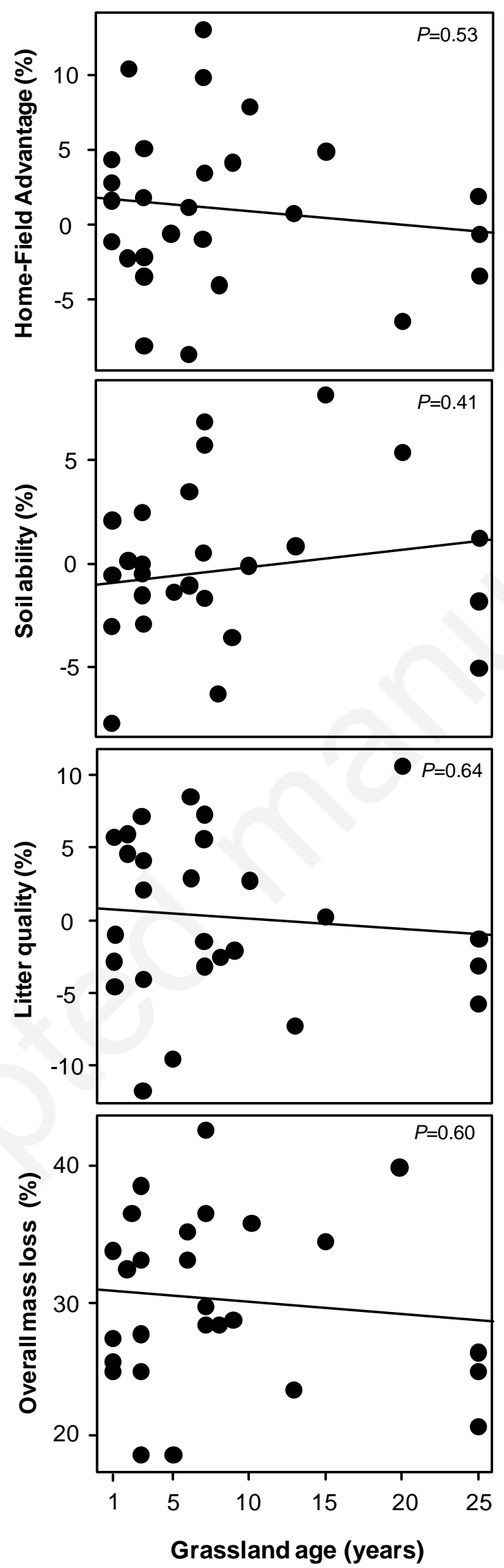

$686 \quad$ Figure 2. 


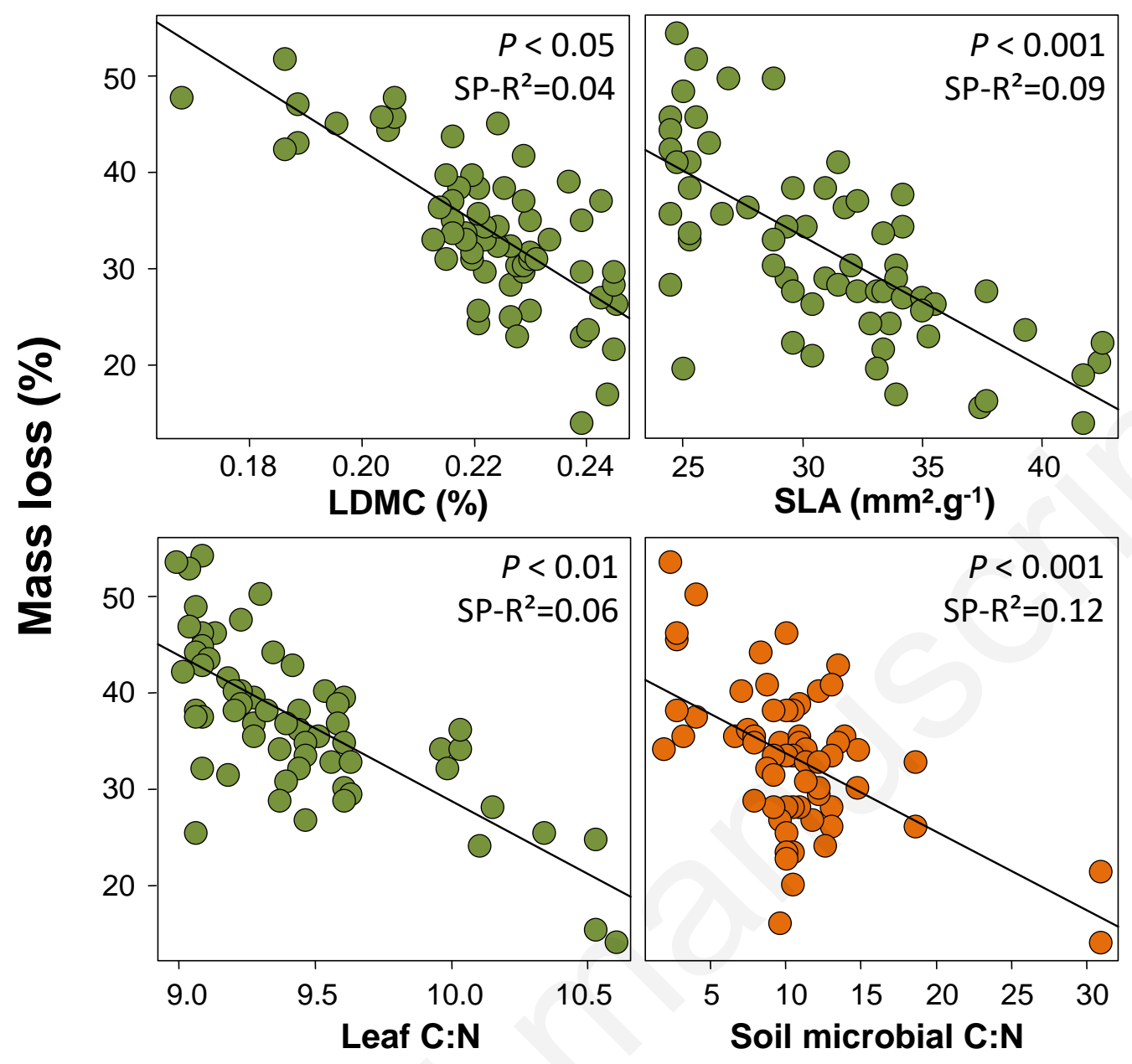

$688 \quad$ Figure 3. 
690 Table S1. Mean values of functional traits measured on plant species representing $80 \%$ of the 691 grassland communities in our experimental design (see Material and Methods) and that were 692 accounted for in the decomposition experiment. Phenolics and LDMC (Leaf Dry Matter 693 Content) are in \%, SLA (Specific Leaf Area) is in $\mathrm{mm}^{2} \cdot \mathrm{g}^{-1}$, and C:N ratio has no unit.

\begin{tabular}{|c|c|c|c|c|c|c|c|c|}
\hline \multirow{3}{*}{ Species } & \multicolumn{8}{|c|}{ Functional traits } \\
\hline & \multicolumn{2}{|c|}{ Phenolics } & \multicolumn{2}{|c|}{$\mathrm{C}: \mathrm{N}$ ratio } & \multicolumn{2}{|c|}{ LDMC } & \multicolumn{2}{|c|}{ SLA } \\
\hline & Mean & SD & Mean & SD & Mean & SD & Mean & SD \\
\hline Agrostis stolonifera & 3.32 & 0.19 & 10.78 & 1.35 & 21.67 & 2.09 & 36.22 & 3.38 \\
\hline Agrostis tenuis & 3.02 & 0.07 & 10.36 & 0.07 & 32.90 & 0.66 & 22.60 & 1.23 \\
\hline Dactylis glomerata & 3.58 & 0.27 & 10.47 & 0.30 & 16.81 & 1.19 & 37.48 & 8.03 \\
\hline Holcus lanatus & 2.92 & 0.09 & 9.79 & 0.16 & 19.92 & 2.40 & 43.53 & 9.50 \\
\hline Lolium italicum & 2.56 & 0.12 & 9.30 & 0.09 & 22.11 & 1.78 & 36.25 & 5.65 \\
\hline Lolium perenne & 2.80 & 0.10 & 9.17 & 0.05 & 25.00 & 2.78 & 22.81 & 2.71 \\
\hline Ranunculus repens & 3.58 & 0.30 & 12.22 & 0.51 & 14.79 & 2.62 & 31.70 & 7.61 \\
\hline Trifolium pratense & 3.82 & 0.15 & 9.36 & 0.20 & 21.31 & 1.45 & 18.90 & 4.59 \\
\hline Trifolium repens & 3.76 & 0.16 & 8.93 & 0.09 & 20.22 & 2.01 & 29.45 & 5.64 \\
\hline
\end{tabular}

695

696

697

698

699

700

701

702 
Table S2. Correlations between plant functional traits, between decomposers and between plant functional traits and decomposers (Leaf Dry Matter Content, LDMC; Specific Leaf Area, SLA). For each correlation, the given parameter is the Pearson's or Spearman's coefficient (depending on the normality of variable distribution) with its significance (*: $P<0.05 ; * * *: P<0.001)$.

\begin{tabular}{|c|c|c|c|c|c|c|c|c|c|c|}
\hline & & & Plant $f$ & nctional traits & & & Decom & osercor & imunity & \\
\hline & & LDMC & SLA & Leaf $\mathrm{C}: \mathrm{N}$ ratio & Phenolics & C:N ratio & Collembola & Acari & Enchytraeidae & Anecics \\
\hline \multirow{3}{*}{ 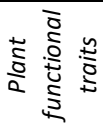 } & SLA & -0.13 & & & & & & & & \\
\hline & Leaf C: $N$ ratio & -0.07 & $0.45^{*}$ & & & & & & & \\
\hline & Phenolics & 0.01 & 0.20 & $0.79 * * *$ & & & & & & \\
\hline \multirow{6}{*}{ 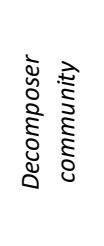 } & Microbial C: $\mathrm{N}$ ratio & -0.34 & 0.26 & 0.26 & 0.18 & & & & & \\
\hline & Collembola & -0.22 & -0.24 & 0.07 & 0.23 & 0.15 & & & & \\
\hline & Acari & $-0.54^{*}$ & 0.14 & 0.39 & 0.35 & $0.43^{*}$ & $0.54^{*}$ & & & \\
\hline & Enchytraeidae & -0.13 & -0.16 & -0.03 & 0.31 & -0.09 & -0.09 & 0.07 & & \\
\hline & Anecis & 0.01 & -0.34 & -0.10 & 0.22 & -0.04 & 0.30 & 0.17 & 0.25 & \\
\hline & Epigeics & 0.08 & 0.04 & 0.02 & -0.01 & -0.17 & -0.23 & -0.10 & 0.40 & 0.14 \\
\hline
\end{tabular}



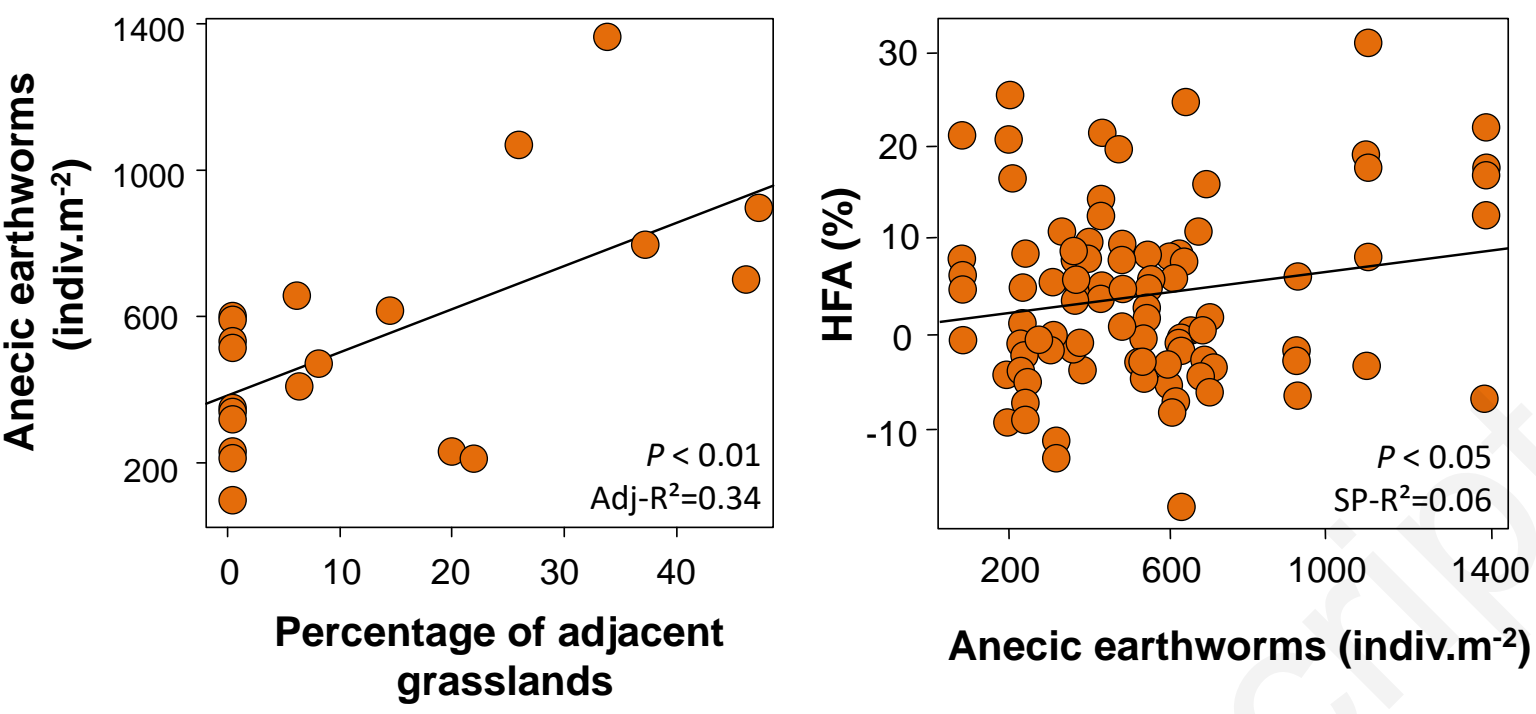

721 Figure S1. Percentage of adjacent grasslands increased the abundance of anecic earthworms, 722 which, in turn, increased Home-Field Advantage (HFA). SP-R ${ }^{2}$ represents semi-partial 723 residuals. See Figure S4 for parameters of models, and see Material and Methods for the transplantation treatment and calculations of HFA. 

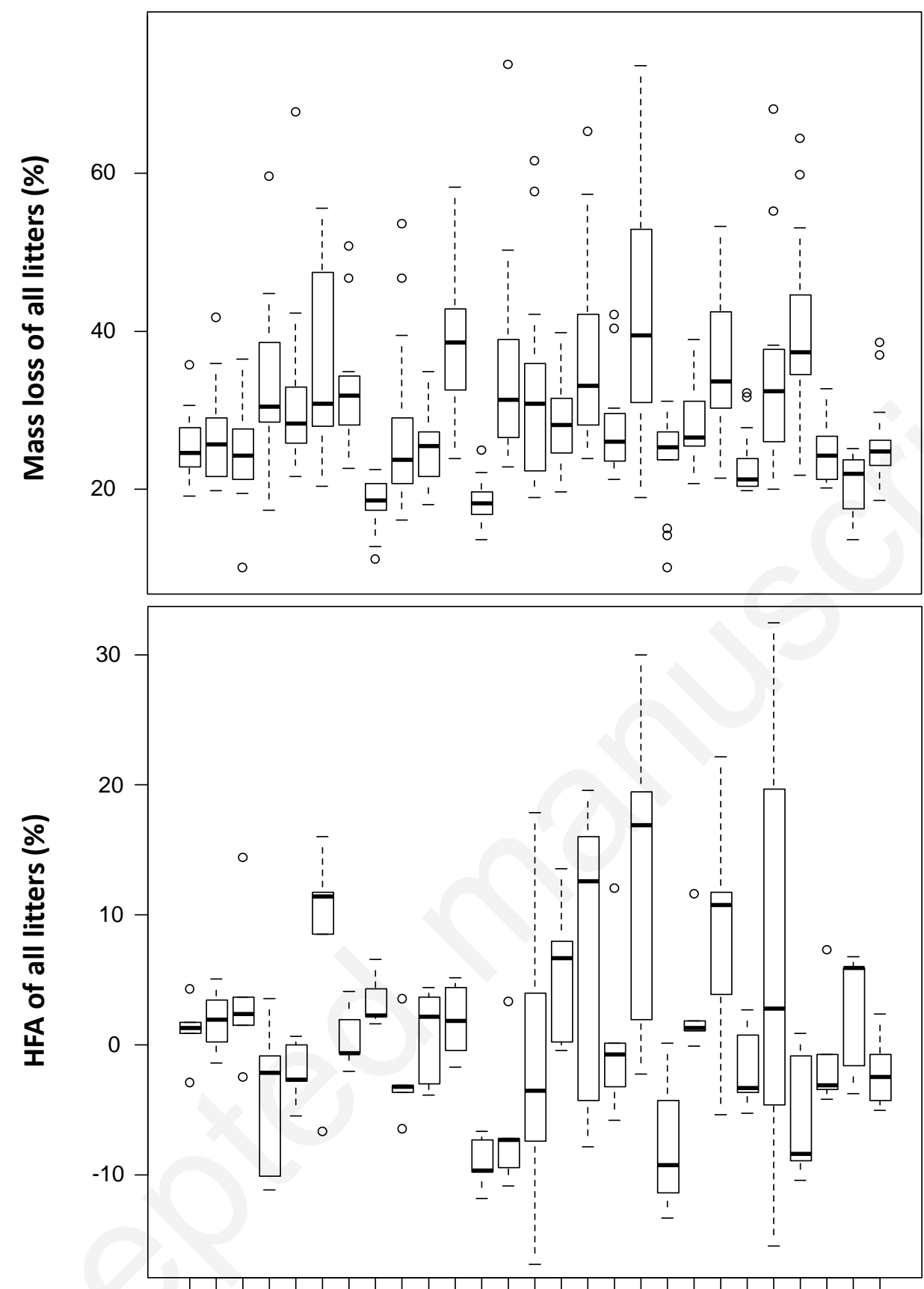

A B CDEFGH I J K L M NOP QR S T UVWXYZAA

Figure S2. Boxplot of mass loss and Home-Field Advantage (HFA) for all litters from the grasslands in our experiment. Grasslands are ordered by age, from the youngest (A, one year old) to the oldest (AA, 25 years old). We observe that, while there is substantial intragrassland variation, there is still important inter-grassland variation for mass loss (ANOVA 739 with grassland as explicative factor: $P<10^{-16}, \mathrm{r}^{2}=0.27$ ) and HFA (ANOVA with grassland as 740 explicative factor: $\left.P=4,9 \times 10^{-4}, \mathrm{r}^{2}=0.23\right)$. 


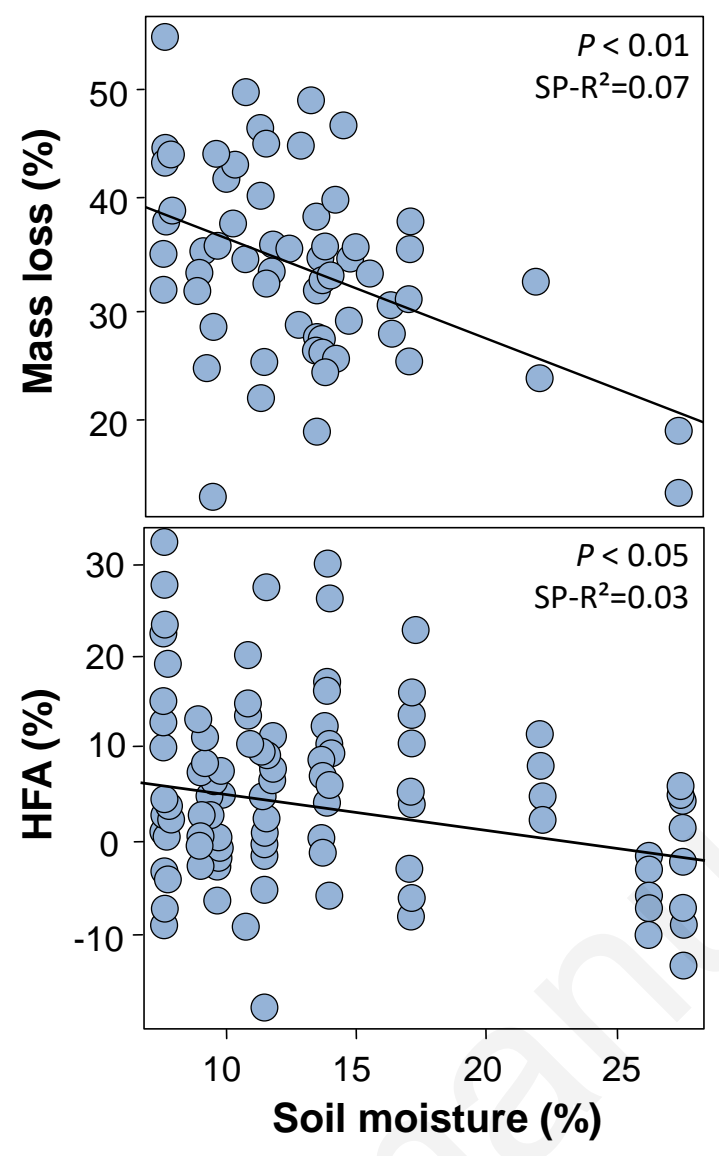

742 Figure S3. Soil moisture decreased litter mass loss and Home-Field Advantage (HFA). SP-R ${ }^{2}$ represents semi-partial residuals. See Results and Figure S4 the model parameters, and see

744 Material and Methods for the transplantation treatment and calculations of HFA.

745

746

747

748

749 


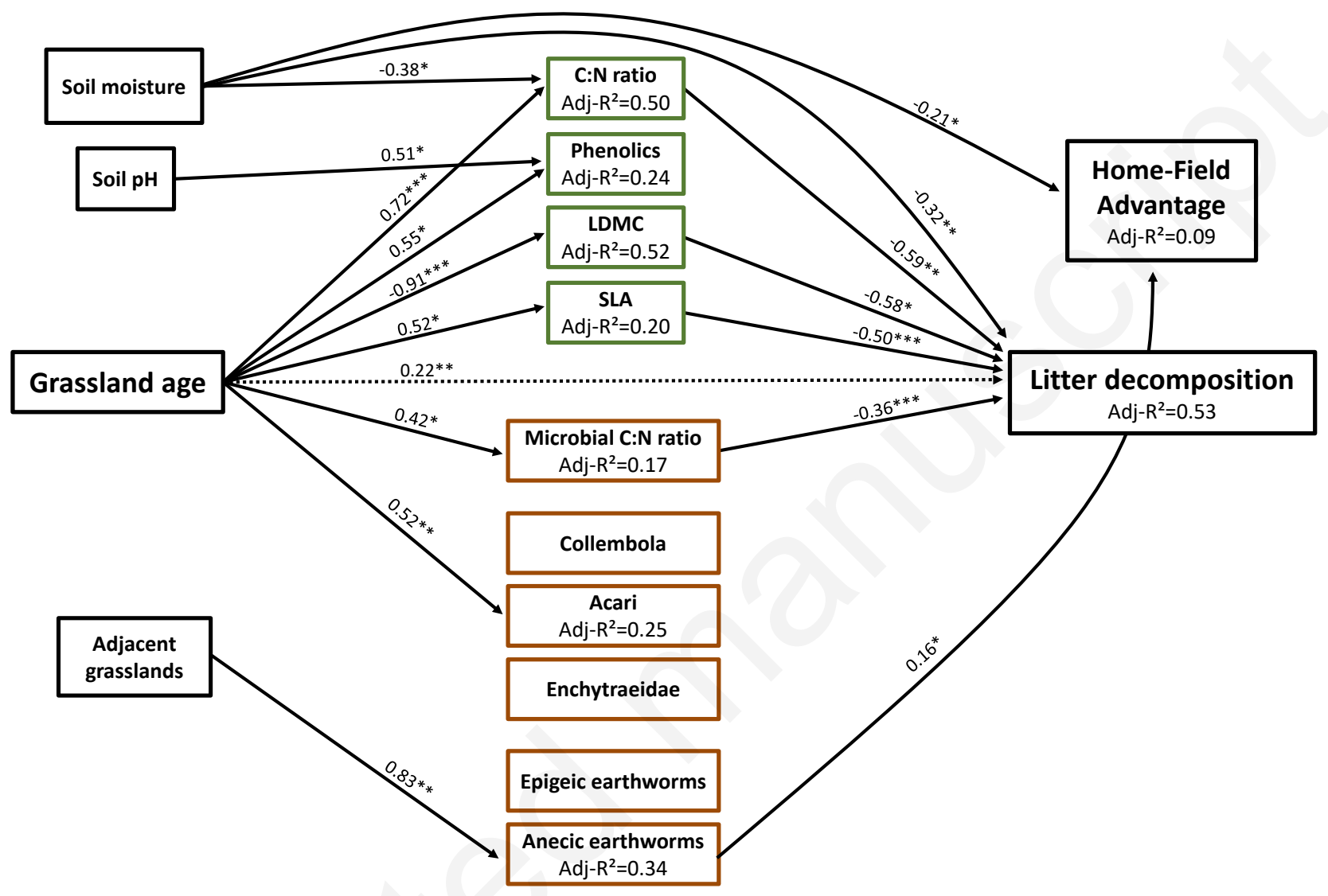

751 Figure S4. Path analysis model for the indirect effects of grassland age on litter mass loss and Home-Field Advantage. These effects are mediated by the functional traits of plant community and by the decomposer community. The figure also presents the effects of abiotic and landscape variables accounted for in the models. Effects are indicated as the standardized regression coefficients of the model, that is the sign and magnitude of the effect. Explained variances are indicated in with each dependent variable, with adj- $\mathrm{R}^{2}$. The dotted line represents a statistically direct effect of grassland age on litter decomposition in the model (i.e. a biological indirect effect of grassland age that was not mediated by any of the parameters that we measured). The relationship between soil $\mathrm{pH}$ and phenolics might be the least causal within the analysis. 


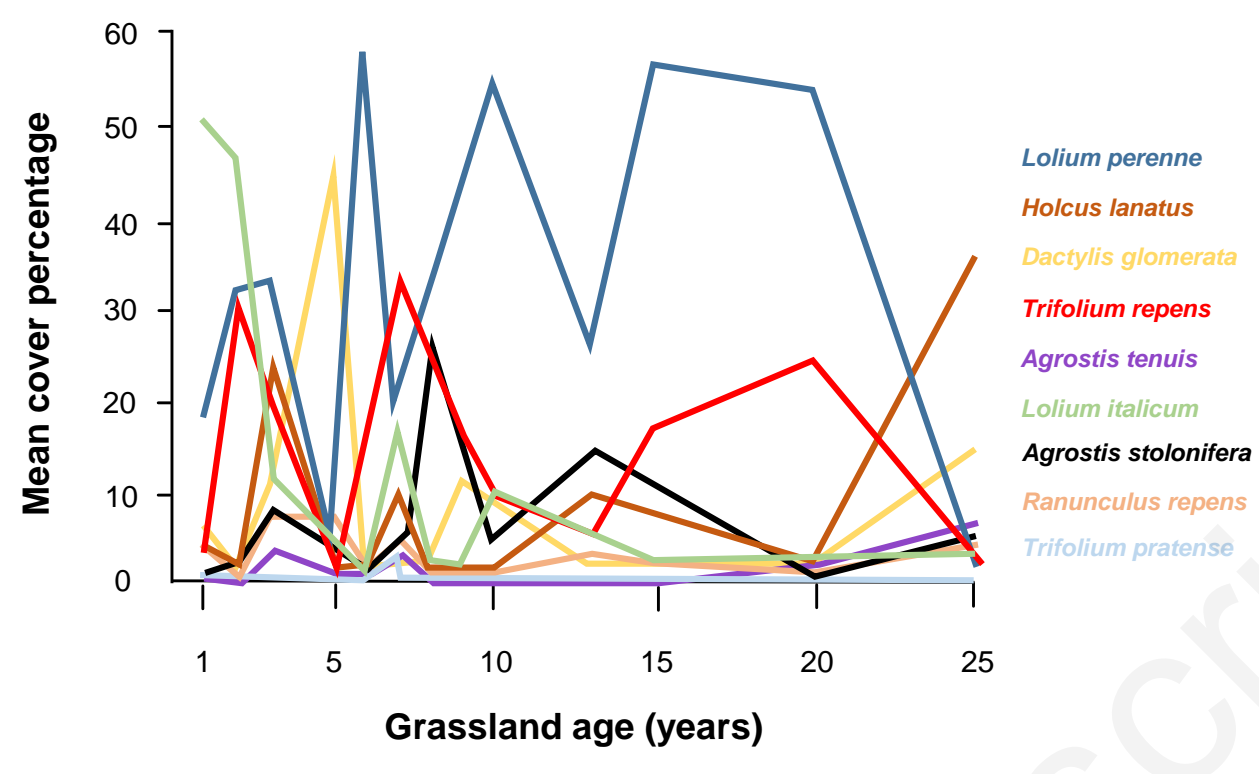

758 Figure S5. Trend lines of mean cover percentage of the nine species used in the 759 decomposition experiment across grassland ageing. These species represent $80 \%$ of the total 760 abundance of the plant community. See Table S1 for species traits. 